\title{
PLANT IN VITRO ART
}

(BITKILLRLE VITRO SANAT)

\author{
Aynur GÜREL ${ }^{1}$, Meltem BAYRAKTAR ${ }^{2}$, Arif ANSIZ ${ }^{3}$, Begüm AKYOL ${ }^{4}$, Esra \\ ÍLHAN ${ }^{5}$, Münire EKMEKÇİGIL ${ }^{6}$, Irmak ANSIZ $^{7},{\text { Berk } \text { ÜNAL }^{8} \text {, Sündüs ÜNAL }}^{9}$, \\ Alpaslan Şevket ACAR ${ }^{10}$, Cana YILAN ${ }^{11}$
}

\begin{abstract}
In this study, plant biotechnology and art are handled together, because art is the most powerful means of bridging differences. This study aims to bring plants of different ecological environments together in various designs by artistic approaches.
\end{abstract}

Keywords: Plant biotechnology, Art, Design

\section{$\ddot{O} \boldsymbol{Z}$}

Sanat farklı dünyaları birleştirmede kullanılabilecek en kuvvetli araç olması sebebi ile bu çalışmada bitki biyoteknolojisi ile sanat aynı çerçevede ele alınmıştır. Değişik ekolojilere ait bitki türlerinin in vitro'da sanatsal yaklaşımlarla farklı tasarımlarda buluşturulması hedeflenmiştir.

Anahtar Kelimeler: Bitki biyoteknolojisi, Sanat, Tasarım

\footnotetext{
${ }^{1}$ Ege Üniversitesi, Mühendislik Fakültesi, Biyomühendislik Bölümü, İZİR, aynurgurel@gmail.com

${ }^{2}$ Ahi Evran Üniversitesi, Mühendislik-Mimarlık Fakültesi, Genetik ve Biyomühendislik Bölümü, KIRŞEHIR, meltembayraktar5@gmail.com (Corresponding Author)

${ }^{3}$ Ege Üniversitesi, Mühendislik Fakültesi, Biyomühendislik Bölümü, IZZMİ, arif.ansiz@gmail.com

${ }^{4}$ Ege Üniversitesi, Mühendislik Fakültesi, Biyomühendislik Bölümü, İZMIR, begumakyol.ege@gmail.com

${ }^{5}$ Ege Üniversitesi, Mühendislik Fakültesi, Biyomühendislik Bölümü, İZMİ, esrailhan01@ gmail.com

${ }^{6}$ Ege Üniversitesi, Fen Bilimleri Enstitüsü, Biyoteknoloji Bölümü, IZMIR, munire.ekmekcigil@gmail.com

${ }^{7}$ Ege Üniversitesi, Fen Bilimleri Enstitüsü, Biyoteknoloji Bölümü, İZMİ, irmakcakinnn@ gmail.com

${ }^{8}$ Ege Üniversitesi, Fen Bilimleri Enstitüsü, Biyoteknoloji Bölümü, IZZMİ, berkunal@yahoo.com

${ }^{9}$ Ege Üniversitesi, Fen Bilimleri Enstitüsü, Biyoteknoloji Bölümü, IZZMIR, sundusunal@ gmail.com

${ }^{10}$ Ege Üniversitesi, Fen Bilimleri Enstitüsü, Biyoteknoloji Bölümü, IZMIR, alpaslansevket@ hotmail.com

${ }^{11}$ Ege Üniversitesi, Mühendislik Fakültesi, Biyomühendislik Bölümü, IZMİR, canan.yilan40@ gmail.com
} 


\section{INTRODUCTION}

Plant in vitro art arises from a combination of science, imagination and skills in an in vitro environment. It ensures science an artistic view of life. Studies in this context aim to touch people by getting out a bit of the pure and experimental features of science by means of art. Thus, science and scientific words will be made clearer in daily life. Science fields will have a chance to become better known by an in vitro art approach [1].

Today, it is popular to develop new designs with different types of plant species, materials, objects and culture vessels by handling in vitro plantlet systems with an aesthetical aim. Presented to the people who want to move away from city-life, stressful business life and monotony and who have as yet had no opportunity to look after plants, in vitro plantlets give a chance to move from laboratories to indoors and also offer aesthetic pleasures as well as their potential in the marketplace on account of their wide product range [1].

This study aims to handle the plant biotechnology and art together and to bring plants of different ecological environments together in various designs by artistic approaches. In addition, this study is an original work and contains new words fort the literature.

\section{MATERIAL AND METHODS}

In vitro plants of different species were designed with various materials, objects and culture vessels in vitro environments and sterile conditions for establishing the in vitro aqua forest, in vitro parks and gardens, in vitro flowering, in vitro glass design works (Figure 1). In addition, various plant species grown in vitro and transferred outdoors were used in ex vitro open terrarium (Figure 2) and ex vitro closed terrarium (Figure 4) works. Also depending on plant growth regulators and nutrient medium composition, some visual beauties can be obtained in vitro conditions as in daffodil plantlets (Figure 3) [1, 2].

\section{RESULTS AND CONCLUSION}

The study we work on gives us the opportunity for dealing with science and discovering amusing things in some of the works we do [1].

The "In Vitro Art" concept can be varied and extended depending on the pleasures, manner and imaginations of people, and it can develop product range of firms dealing with plant tissue culture.

After in a certain period of time, medium gets dry. Therefore, moving plantlets from in vitro terraria to outdoors can ensure their permanency. Implementation of this process can be explained by developing a user guide.

Terraria ensure both aesthetics and ecosystem. They are different from classical terraria because plantlets are grown in vitro conditions, and also they ensure study on the tested plants free from pathogens. 


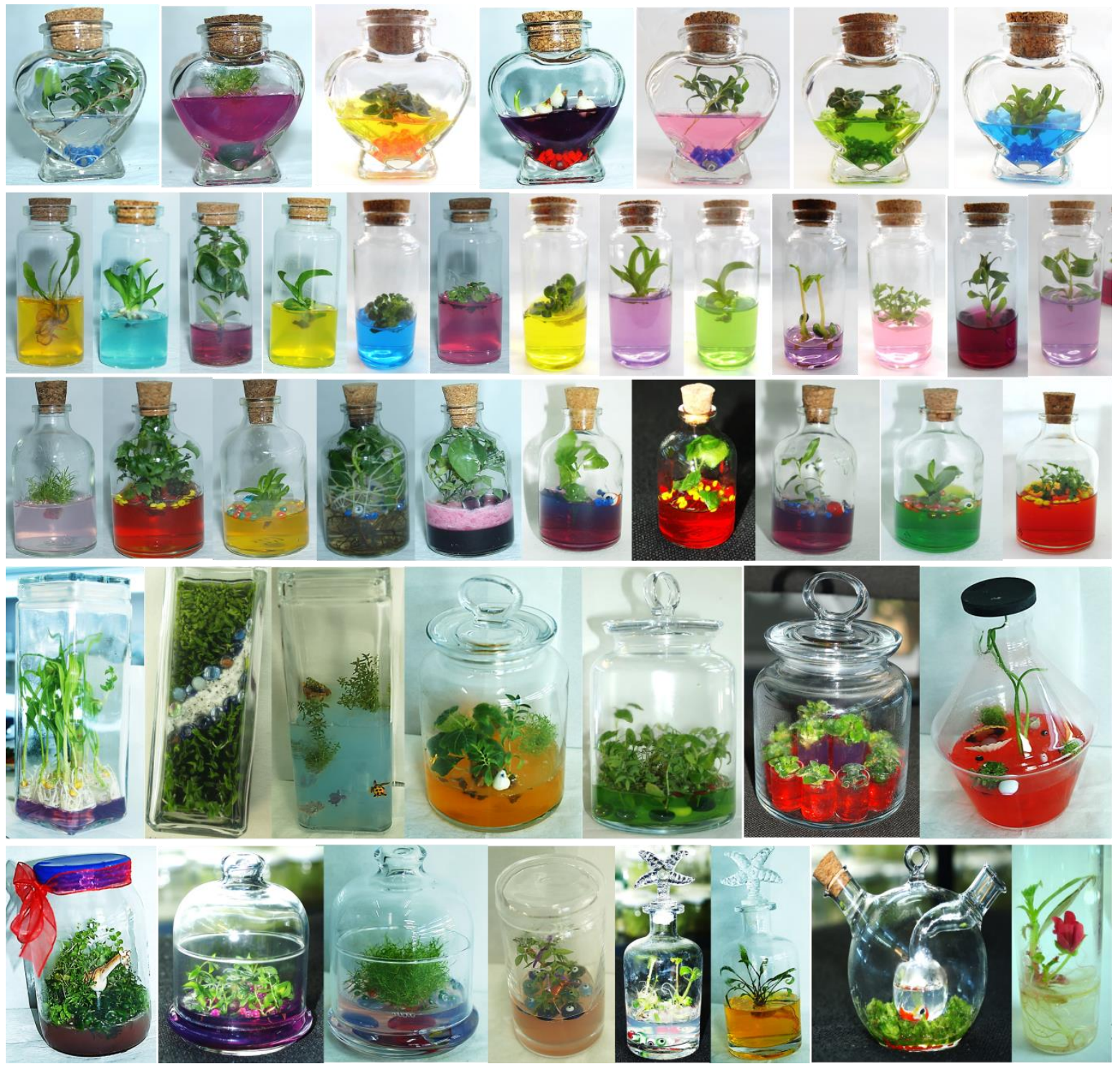

Figure 1. Some samples for plant in vitro art [1] 

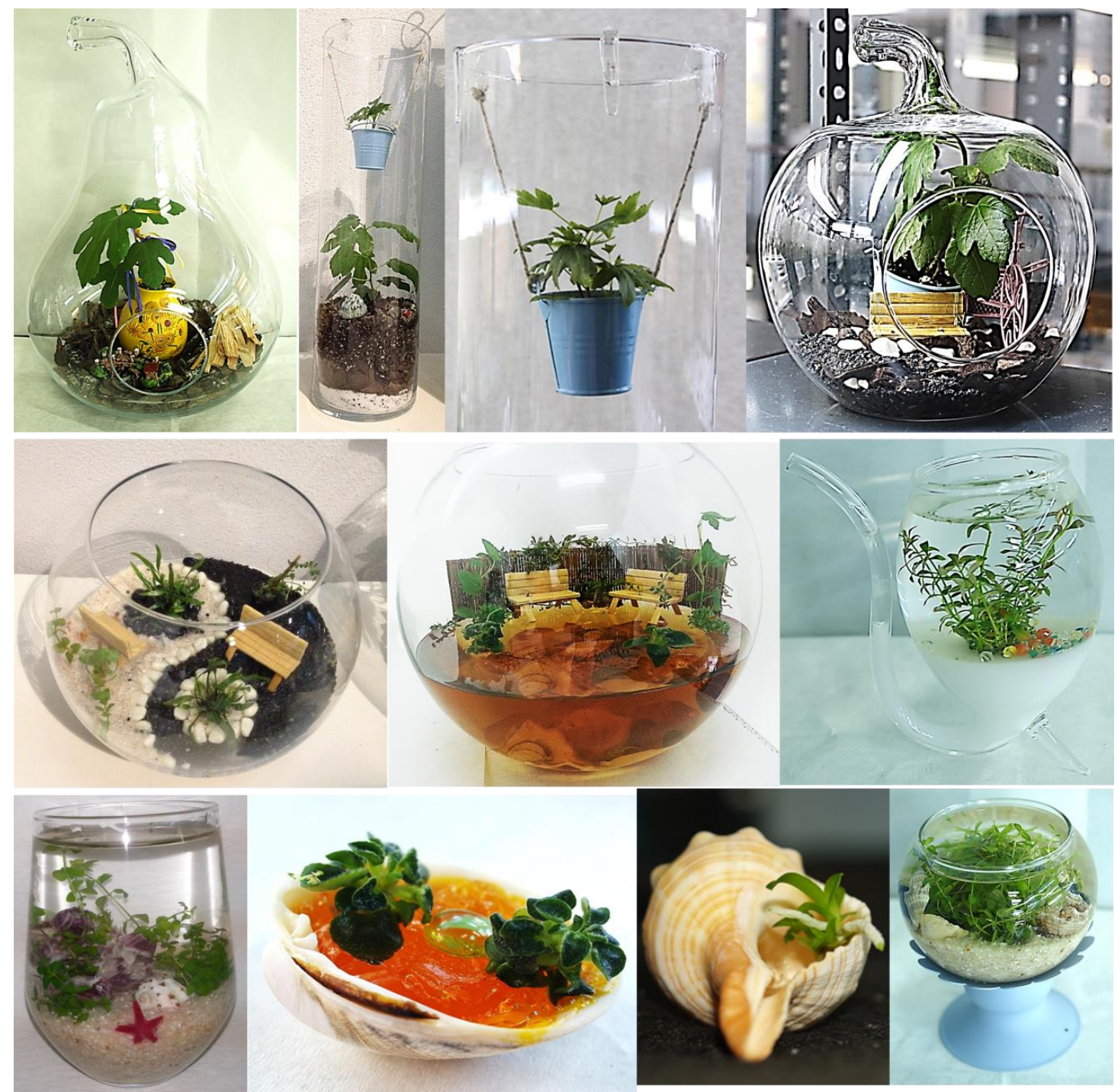

Figure 2. Some samples for ex vitro open terrarium [1]

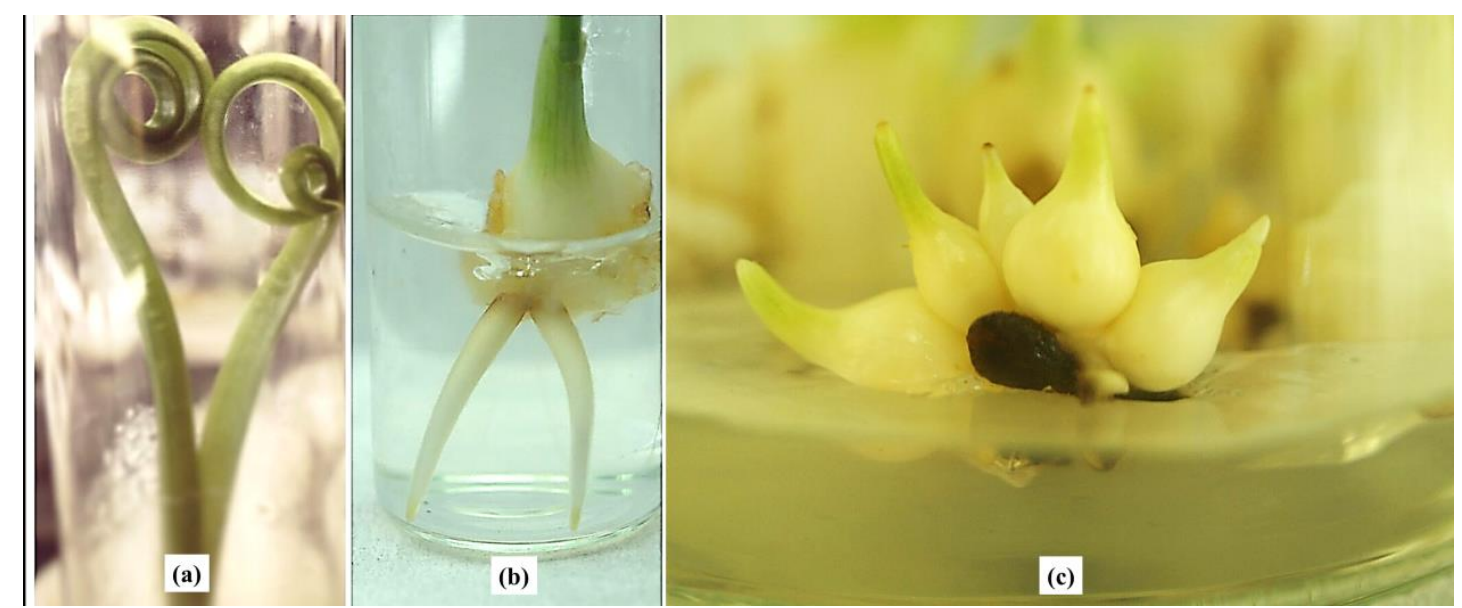

Figure 3. Daffodils were developed in vitro conditions: a: Heart shaped leaves in vitro; b: Ballerina legs in vitro; c: Sisterhood of narcissus bulblets in vitro [2] 


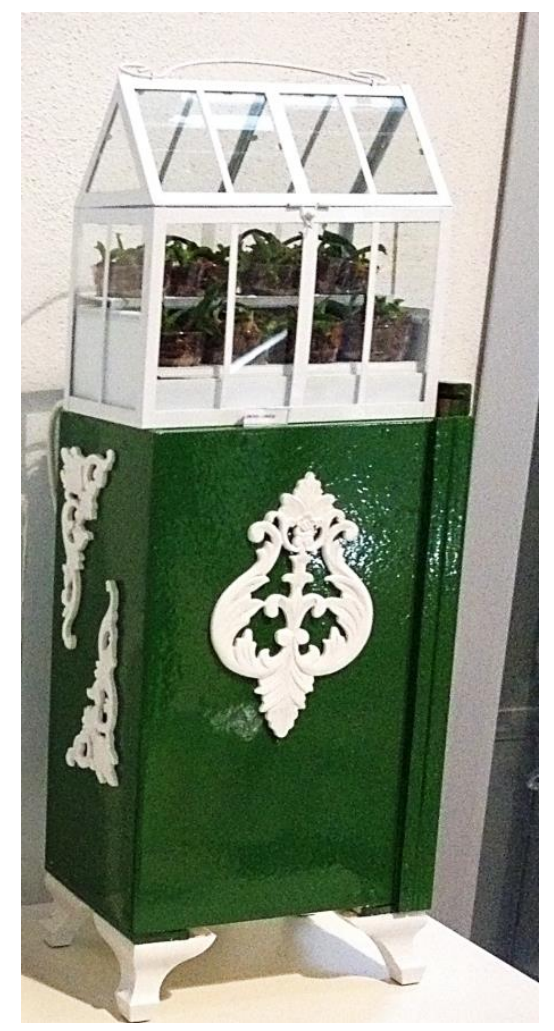

Figure 4. Ex vitro closed terrarium [1]

\section{ACKNOWLEDGEMENT}

The authors would like to thank ALGEN Biotechnology Company in Istanbul/Turkey.

\section{REFERENCES}

[1] Gürel A, Bayraktar M, Ansız A, Akyol B, İlhan E, Ekmekçigil M, Ansız I, Ünal B, Ünal S, Acar AS. Plant in Vitro Art, VII International Bioengineering Congress (BEC 2015 Biodesign Solutions of Nature for Societal Challenges9, 2015, p. 71.

[2] Gürel A, Bayraktar M, Yılan C. Bioengineering as Art, VIIth International Bioengineering Congress (BEC 2015-Biodesign Solutions of Nature for Societal Challenges), 2015.

\section{CV/ÖZGEÇMiș}

\section{Aynur GÜREL; Prof. Dr. (Professor)}

She got her bachelors' degree in the Field Crops Department at Ege University, Izmir/Turkey in 1982, her master degree in the Field Crops Department at Ege University, Izmir/Turkey in 1984, PhD degree in the Field Crops Department at Ege University, Izmir/Turkey in 1989. She is still an academic member of the Bioengineering Department at Ege University. Her major areas of interest are: Plant Tissue Culture, Plant Stress Physiology, Plant Biotechnology and Bioengineering.

Lisans derecesini 1982'de İzmir Ege Üniversitesi Tarla Bitkileri Bölümü'nden, Yüksek Lisans derecesini 1984'de İzmir Ege Üniversitesi Tarla Bitkileri Bölümü'nden, Doktora derecesini 1989 yılında İzmir Ege Üniversitesi Tarla Bitkileri Bölümü'nden aldl. Hala Ege Üniversitesi Biyomühendislik Bölümü'nde ögretim üyesi olarak çalışmaktadır. Temel çalışma alanlarl; Bitki Doku Kültürü, Bitki Stres Fizyolojisi, Bitki Biyoteknolojsi ve 
Biyomühendislik üzerinedir.

\section{Meltem BAYRAKTAR; Yrd. Doç. Dr. (Assistant Professor)}

She got her bachelors' degree in the Biology Department at Ege University, Izmir/Turkey in 2000, her master degree in the Biotechnology Department at Ege University, Izmir/Turkey in 2004, PhD degree in the Biotechnology Department at Ege University, Izmir/Turkey in 2013. She is still an academic member of the Genetic and Bioengineering Department at Ahi Evran University. Her major areas of interest are: Plant Tissue Culture and Bioengineering.

Lisans derecesini 2000'de İzmir Ege Üniversitesi Biyoloji Bölümü'nden, Yüksek Lisans derecesini 2004'de İzmir Ege Üniversitesi Biyoteknoloji Bölümü'nden, Doktora derecesini 2013 yllında İzmir Ege Üniversitesi Biyoteknoloji Bölümü'nden aldl. Hala Ahi Evran Üniversitesi Genetik ve Biyomühendislik Bölümü'nde ögretim üyesi olarak çalışmaktadır. Temel çalışma alanları; Bitki Doku Kültürü ve Biyomühendislik üzerinedir.

\section{Arif ANSIZ; Yüksek Biyomühendis (Msc. Bioengineer)}

He got his bachelors' degree in the Bioengineering Department at Ege University, Izmir/Turkey in 2011. his master degree in the Bioengineering Department at Ege University, Izmir/Turkey in 2015. He has been working at ALGEN Biotechnology Company. His major area of interest are: Plant Tissue Culture and Bioengineering.

Lisans derecesini 2011'de İzmir Ege Üniversitesi Biyomühendislik Bölümü’nden, Yüksek Lisans derecesini 2015'de İmir Ege Üniversitesi Biyomühendislik Bölümü'nden aldl. ALGEN Biyoteknoloji'de çalışmaktadır. Temel çalışma alanlarl; Bitki Doku Kültürü ve Biyomühendislik üzerinedir.

\section{Begüm AKYOL; Araştırma Görevlisi (Research Assistant)}

She got her bachelors' degree in the Bioengineering Department at Ege University, Izmir/Turkey in 2011, her master degree in the Bioengineering Department at Ege University, Izmir/Turkey in 2015. She is a student in the Bioengineering PhD program at The Graduate School of Natural and Applied Sciences of Ege University and has been working as a research assistant at Bioengineering Department of the same university. Her major areas of interest are: Plant Tissue Culture and Bioengineering.

Lisans derecesini 2011'de İzmir Ege Üniversitesi Biyomühendislik Bölümü'nden, Yüksek Lisans derecesini 2015'de İzmir Ege Üniversitesi Biyomühendislik Bölümü'nden aldl. Ege Üniversitesi Fen Bilimleri Enstitüsü Biyomühendislik Doktora Programı'nda öğrencidir ve aynı üniversitenin Biyomühendislik Bölümü'nde araştırma görevlisi olarak çallşmaktadır. Temel çalışma alanları; Bitki Doku Kültürü ve Biyomühendislik üzerinedir.

\section{Esra İLHAN; Araştırma Görevlisi (Research Assistant)}

She got her bachelors' degree in the Bioengineering Department at Ege University, Izmir/Turkey in 2012, her master degree in the Bioengineering Department at Ege University, Izmir/Turkey in 2015. She is a student in the Bioengineering PhD program at The Graduate School of Natural and Applied Sciences of Ege University and has been working as a research assistant at Bioengineering Department of the same university. Her major areas of interest are: Plant Tissue Culture and Bioengineering.

Lisans derecesini 2012'de İzmir Ege Üniversitesi Biyomühendislik Bölümü'nden, Yüksek Lisans derecesini 2015'de İzmir Ege Üniversitesi Biyomühendislik Bölümü'nden aldl. Ege Üniversitesi Fen Bilimleri Enstitüsü Biyomühendislik Doktora Programı'nda ögrencidir ve aynı üniversitenin Biyomühendislik Bölümü'nde araştırma görevlisi olarak çalışmaktadır. Temel çalışma alanlarl; Bitki Doku Kültürü ve Biyomühendislik üzerinedir.

\section{Münire EKMEKÇİGíL; Yüksek Biyolog (Msc. Biologist)}

She got her bachelors' degree in the Biology Department at Ankara University, Ankara/Turkey in 2003, her master degree in the Biology Department at Ankara University, Ankara/Turkey in 2006. She is a student in the Biotechnology PhD program at The Graduate School of Natural and Applied Sciences of Ege University. Her major area of interest is: Plant Tissue Culture.

Lisans derecesini 2003 'de Ankara Üniversitesi Biyoloji Bölümü’nden, Yüksek Lisans derecesini 2006'da Ankara Üniversitesi Biyoloji Bölümü'nden aldl. Ege Üniversitesi Fen Bilimleri Enstitüsü Biyoteknoloji Doktora 
Programı'nda öğrencidir. Temel çalışma alanı Bitki Doku Kültürü üzerinedir.

\section{Irmak ANSIZ; Yüksek Biyoteknolog (Msc. biotechnologist)}

She got her bachelors' degree in Molecular Biology and Genetics Department at İstanbul Kültür University, Istanbul/Turkey in 2011, her master degree in the Biotechnology Department at Ege University, Izmir/Turkey in 2015. She has been working at ALGEN Biotechnology Company. Her major area of interest is: Plant Tissue Culture.

Lisans derecesini 2011'de İstanbul İstanbul Kültür Üniversitesi Moleküler Biyoloji ve Genetik Bölümü'nden, Yüksek Lisans derecesini 2015'de İmir Ege Üniversitesi Biyoteknoloji Bölümü'nden aldl. ALGEN Biyoteknoloji'de çalışmaktadır. Temel çalışma alanı Bitki Doku Kültürü üzerinedir.

\section{Berk ÜNAL; Yüksek Ziraat Mühendisi (Msc. Agricultural Engineer)}

He got his bachelors' degree in the Horticulture Department at Gaziosmanpaşa University, Tokat/Turkey in 2008, his master degree in the Horticulture Department at Gaziosmanpaşa University, Tokat/Turkey in 2011. He is a student in the Biotechnology PhD program at The Graduate School of Natural and Applied Sciences of Ege University. His major area of interest is: Plant Tissue Culture.

Lisans derecesini 2008'de Tokat Gaziosmanpaşa Üniversitesi Bahçe Bitkileri Bölümü’nden, Yüksek Lisans derecesini 2011'de Tokat Gaziosmanpaşa Üniversitesi Bahçe Bitkileri Bölümü'nden aldı. Ege Üniversitesi Fen Bilimleri Enstitüsü Biyoteknoloji Doktora Programı'nda öğrencidir. Temel çalışma alanı Bitki Doku Kültürü üzerinedir.

\section{Sündüs ÜNAL; Dr. (Ph.D.)}

She got her bachelors' degree in the Field Crops Department at Ege University, Izmir/Turkey in 1998, her master degree in the Biotechnology Department at Ege University, Izmir/Turkey in 2006, PhD degree in the Biotechnology Department at Ege University, Izmir/Turkey in 2013. Her major areas of interest is: Plant Tissue Culture.

Lisans derecesini 1998'de İzmir Ege Üniversitesi Tarla Bitkileri Bölümü'nden, Yüksek Lisans derecesini 2006'da İmir Ege Üniversitesi Biyoteknoloji Bölümü'nden, Doktora derecesini 2013 yılında İzmir Ege Üniversitesi Biyoteknoloji Bölümü'nden aldı. Temel çalışma alanı Bitki Doku Kültürü üzerinedir.

\section{Alpaslan Şevket ACAR; Ziraat Mühendisi (Agricultural Engineer)}

He got his bachelors' degree in the Field Crops Department at Selçuk University, Konya/Turkey in 2011. He is a student in the Biotechnology MSc program at The Graduate School of Natural and Applied Sciences of Ege University and has been working at ALGEN Biotechnology Company. His major area of interest is: Plant Tissue Culture.

Lisans derecesini 2011'de Konya Selçuk Üniversitesi Tarla Bitkileri Bölümü’nden aldı. Ege Üniversitesi Fen Bilimleri Enstitüsü Biyoteknoloji Yüksek Lisans Programı'nda ögrencidir ve ALGEN Biyoteknoloji'de çalışmaktadır. Temel çalışma alanı Bitki Doku Kültürü üzerinedir.

\section{Canan YILAN; Biyomühendis (Bioengineer)}

She got her bachelors' degree in the Bioengineering Department at Ege University, Izmir/Turkey in 2014. She is a student in the Bioengineering MSc program at The Graduate School of Natural and Applied Sciences of Ege University. Her major areas of interest are: Plant Tissue Culture and Bioengineering.

Lisans derecesini 2014'de İzmir Ege Üniversitesi Biyomühendislik Bölümü'nden aldı. Ege Üniversitesi Fen Bilimleri Enstitüsü Biyomühendislik Yüksek Lisans Programı'nda öğrencidir. Temel çalışma alanları; Bitki Doku Kültürü ve Biyomühendislik üzerinedir. 